Earth Common Journal Regular Issue

Everyday Activism

MacEwan University

Volume 4, Number 1, September 2014

\title{
Edmonton Hiphop Kulture: Techniques of self and cultural sustainability
}

\author{
Diana Pearson, Roya Yazdanmehr* \\ MacEwan University, Canada
}

\begin{abstract}
The word culture is rich with complex meanings and despite its use in common speech little is known about it and even less about the practices that contribute to 'its' continued existence, what might be called cultural sustainability. Edmonton Hiphop Kulture ${ }^{i}$ :Techniques of Self and Cultural Sustainability documents the role of techniques of self, defined as the daily practices an individual uses to transform his or her body, soul, thought and conduct of being (Foucault, 1988, p. 18), in the development and maintenance of Hiphop Kulture in Edmonton, Alberta. Using a Critical Constructivist methodology, the researchers document the weekly creation of Hiphop Kulture knowledge at Cipher5, a knowledge circle organized by Hip Hop specialists Andre Hamilton, Don Welsh, and MacEwan University professor Dr. Michael B. MacDonald. With Michel Foucault's (1988) theory in mind that culture is a form of administration built by techniques of production, signification, domination and self (Kendall \& Wickham, 1999, pp. 3-54), this paper documents the researchers' exploration of techniques of self in Hiphop Kulture. The researchers theorize that these techniques, or cultural practices, include self-expression, belonging, and identity development and that these three techniques encourage the sustainability of Edmonton Hiphop Kulture. Research methods include participant observation at weekly Cipher5 meetings, autoethnography, interviews with Cipher5 members, and a literature review including a critical hermeneutic analysis of Hiphop literature.
\end{abstract}




\section{Introduction}

The word culture is rich with complex meanings and despite its use in common speech, little is known about it and even less about the practices that contribute to 'its' continued existence, what might be referred to as cultural sustainability. Michel Foucault (1988) has suggested that culture is a form of administration built by techniques of production, signification, domination, and self (p. 18). Foucault's idea is that individuals find and make use of techniques that make themselves and culture at the same time (Kendall \& Wickham,1999, pp.3-54). Given this perspective, the researchers hypothesize that the sustainability of a culture relies on the continued use of these specialized techniques. The alternative therefore might also be true; the disuse of techniques will lead to the dissolution of culture. This article showcases the techniques of self practiced in Hiphop Kulture, shared in Cipher5, and that they contribute to the sustainability of Edmonton Hiphop.

\section{Roots}

KRS-ONE (2009), master emcee and Hip Hop pioneer, identifies and defines various components within the culture (p. 80). These individual components are defined as Hiphop Kulture, Hiphop, Hip Hop, and hip-hop. Hiphop Kulture is "the manifested character, patterns, beliefs, sciences and arts" of "an international community of specialized urban people" (2000, Temple of Hip Hop, para. 5); Hiphop is "the creative, causative force behind Hip Hop's elements" (2009, p. 80); Hip Hop is "the creation and development of Breakin, Emceein, Graffiti Art, Deejayin, Beat Boxin, Street Fashion, Street Language, Street Knowledge, and Street Entrepreneurialism” (p. 80); and hip-hop is "rap music product and those things and events associated with Rap music entertainment-hip-hop is a music genre" (p. 80). These spellings are used throughout this paper to specify the individual components of Hiphop Kulture.

Hip-hop [rap music] is often claimed by hiphoppas to be misunderstood. Despite there being more than three dozen sub-genres of hip-hop (Rabaka, 2013, p. 286), most of which emphasize social, political, and racial equality, rap music has been commodified, reducing its mass distribution to two styles: commercial and gangsta rap (p. 286). Rabaka refers to these two styles as "the ghetto-gangsta-nigga-pimp-hoe-thug theme" (p. 6). The exploitation of these sub-genres has "critics of the genre [arguing] that rap reinforces misogyny, glorifies drug culture, and advocates violence. Some believe that it contributes to self-destructive behaviours for its youth consumers who try to mimic the attitudes and lifestyles of their favorite rap icons" (Alvarez, 2012, p. 123). 
Historically, "Hip-hop emerged during the decline of both the civil rights and Black Power movement" (MacDonald, 2012, p. 95) out of a need for a marginalized group to express itself in opposition to the hegemony of the dominant culture of the period (Rabaka, 2013, p. 291). In fact, "for many youth of color, rap music is not seen as a destructive force; it's seen as an asset. It provides an outlet for expression" (Alvarez, 2012, p. 123).

Following the rise of hip-hop as a genre, KRS-ONE (2000) played a role in the development of Hiphop Kulture. He established the "Stop the Violence Movement" in 1989 and founded the Temple of Hip Hop, a cultural organization that frames Hiphop as a lifestyle and a spiritual practice. The Temple of Hip Hop builds upon the principles and philosophy written in KRS-ONE's The Gospel of Hip Hop (2009). These principles challenge the media's commercialization of hip-hop and instead highlight Hiphop Kulture as an international community of peace:

This Hip Hop Declaration of Peace guides Hiphop Kulture toward freedom from violence, and establishes advice and protection for the existence and development of the international Hiphop community. Through the principles of this Hip Hop Declaration of Peace we, Hiphop Kulture, establish a foundation of Health, Love, Awareness, Wealth, peace and prosperity for ourselves, our children and their children's children, forever. (KRS-ONE, 2009, p. 552)

These practices are alive in Edmonton, Alberta, in a Hiphop knowledge-sharing circle called Cipher5. ${ }^{\text {ii }}$ Artists and lovers of hip-hop music attend the circle weekly in a downtown Edmonton café. Facilitated by Hip Hop specialists Andre Hamilton (Dre Pharoh), Don Welsh (ID), and MacEwan University professor Dr. Michael B. MacDonald, the goal of the group is to explore the foundational practices of Hip Hop through real-life issues by discussing everything from the history of Hip Hop to postcolonialism to sexuality to making beats. Modeled after Paulo Freire's "culture circle" (MacDonald, 2012, p. 101), Cipher5 is an opportunity for artists to make connections and build knowledge as a path to personal growth through conscientização, the development of critical consciousness (Freire, 1974, pp. 37-51). Sometimes documentaries are shown (United States of Africa, the Art of Rap), and excerpts are often read from The Gospel of Hip Hop to lead group conversations. Cipher5 has been active for three years and was recently awarded the title "Temple of Hip Hop Canadian Chapter" by KRS-ONE (A. Hamilton, personal communication, May 27, 2014).

The researchers attended Cipher5 as a cultural research environment where techniques of Hiphop Kulture are studied. Through autoethnography and participatory observation, the researchers theorized that the following techniques of self ${ }^{\text {fii }}$, defined as 
the daily practices an individual uses to transform his or her body, soul, thought and conduct of being (Foucault, 1988, p. 18), contribute to Hiphop Kultural sustainability in Edmonton: belonging, self-expression, and identity building. This paper is organized into two sections: the first presents the research findings on belonging and selfexpression in Cipher5. The second section focuses on how identity is developed through the elements of Hip Hop and in Cipher5.

\section{Research Design}

This paper derives from the researchers' work with ethnomusicologist and MacEwan University professor Dr. Michael B. MacDonald. MacDonald (2014) began Cipher5 to study how the techniques of culture contribute to the understanding of how music cultures operate and how Cultural Aesthetics function (p. 435). The research findings were determined through participatory observation and autoethnography from the researchers' attendance at Cipher5 and through interviews with members of the Edmonton Hip Hop community.

\section{Belonging and Self-expression}

The researchers began attending Cipher5 meetings with minimal prior knowledge or experience of Hiphop cultural practices. Despite this minimum background, the researchers found themselves accepted and encouraged by the community of practitioners to participate in the knowledge circle. The regular attendees created an environment where inquisitive minds contributed and found a place of belonging in a culture they may not have previously identified with. This welcoming nature was in part created by the open circle formation, where individuals came together as equal, valuable participants in the discussion. The group challenged and critiqued shared opinions and learned from each other through critical discussion of frequently explored, controversial topics such as racism, sexuality, drug use, and postcolonialism. This is the process of critical exploration as described in bell hooks' Yearning (1990) in which "committed cultural critics - whether white or black, scholars or artists - can produce work that opposes structures of domination, that presents possibilities for a transformed future by willingly interrogating their own work on aesthetic and political grounds” (p. 55).

In her essay A Community of Care, hooks (2009) explored "a culture of belonging" (p. 216) as an idea of community that emerges from intimate relationships with others: "As we work with others, and as we endeavour to get to know them, we learn to appreciate them in their depth and integrity and with a better appreciation for their potential and need" (Krocker, as cited in hooks, 2009, p. 228). Using autoethnography, the researchers have developed a deeper understanding of themselves and the community of Edmonton 
hiphoppas through the process of getting to know each other in Cipher5. hooks shared her perception of the pronounced disconnection between people and individual purpose:

Again and again as I travel around I am stunned by how many citizens in our nation feel lost, feel bereft of a sense of direction, feel as though they cannot see where our journeys lead, that they cannot know where they are going. Many folks feel no sense of place. (hooks, 2009, p. 1)

hooks (2009) recognized this lack of belonging as an "everyday anguish," a widespread social experience that divorces us from a sense of purpose, which she defined as "the making of lives that we feel are worth living" (p.1). As stated above, building relationships with others may facilitate a process that leads to community. In Cipher5 people of all backgrounds, gender, race and age come together to join in the production of new knowledge through critical discussion. This knowledge is created through the techniques of expression, belonging and relationship-building. As such, the following explored Cipher5 as a culture of belonging and a place for self-expression through which hiphoppas are made into subjects of culture, in turn contributing to the sustainability of Edmonton Hiphop Kulture.

A key component in creating a culture of belonging is the creation of a safe environment in which all participants feel acknowledged, accepted and appreciated: "Marginalized or traditionally voiceless students must have a safe arena in which to develop creative expression" (Wang, 2010, p. 68). A local high school program called The Beat of Boyle Street created a non-threatening environment for marginalized youth. Instead of forcing and coercing a structured method of education, these instructors created a curriculum that used beat making and rapping as tools for facilitating student engagement in the education system. This type of program was suitably developed and implemented in Edmonton, which is home to the highest urban Aboriginal population of any Canadian city (Environics, 2010, p. 17), and where secondary school drop-out rates for Aboriginal youth are significant (p. 15). An unsafe, threatening environment becomes welcoming when students are encouraged to express themselves in the art forms by which they naturally gravitate towards. This form of student-led creative activity created a culture of belonging where students felt safe to express themselves by using the elements of Hip Hop as techniques of self.

The medium of this expression should honor their prior knowledge and skills rather than be a rigid form of language or a generic activity deemed "literate" or "educational" or "valued" by the dominant culture. Youth must be in control of their own representation. (Wang, 2010, p. 68) 
By engaging in this method, students were able to become participants of Hiphop Kulture, and through their practices contribute to the sustainability of Edmonton Hiphop.

Beat making and rapping are also used as techniques of self-expression by social worker and pioneer of HipHop therapy, Tomás Alvarez III in his youth program Beats, Rhymes, and Life in Oakland, California:

The notion of rap as a form of catharsis dates back to the early days of rap music and Hip-Hop culture. In the 1970s African American and Latino youth began using rap and other elements of Hip-Hop ... a as cathartic and social outlets to deal with harsh conditions found in their neighborhoods. Through rap, disenfranchised youth were able to cope with stress, build support groups, speak out about the conditions in the neighborhood, and gain a sense of identity. (Alvarez, 2012, p. 123)

The researchers found similarities between how the participants of Beats, Rhymes and Life and Cipher5 have used the Hip Hop elements as a technique of self-expression for the purposes of self-empowerment. Participants of Cipher5 share how they have used the elements of Hip Hop as a way of overcoming personal difficulties, even referring to Cipher5 as a "therapy circle" by the facilitators themselves (A. Hamilton, personal communication, Feb 10, 2014). For example, a well-respected DJ in the circle "never even used to speak" (A. Hamilton, personal communication, Feb 10, 2014); for the first year of attendance, he remained a silent observer. Now, he shares his vast knowledge of Hiphop Kulture at great length, even allowing himself to be interviewed and recorded by fellow artist KazMega on his album Everybody's KINg (2014). Through self-expression, this DJ and Hip Hop specialist actively shares his knowledge in Cipher5 meetings, and in doing so contributes to the sustainability of Edmonton Hiphop Kulture.

This section has demonstrated how a culture of belonging and self-expression are used as techniques of self. Foucault (1988) defines techniques of self as the following:

... processes which permit individuals to effect by their own means or with the help of others a certain number of operations on their own bodies and souls, thoughts, conduct and way of being, so as to transform themselves in order to attain a certain state of happiness, purity, wisdom, perfection, or immortality. (p.18)

It is through this transformative process that individuals contribute to the creation of a deeper level of understanding, acknowledging the emotional, physical, spiritual, social and economic ingredients that make up a community and a culture. By developing a culture of belonging and utilizing practices of self-expression, hiphoppas are able to practice the techniques of self that contributes to the sustainability of Hiphop Kulture. 


\section{Identity Development}

The terms identity and culture are abstract, frustrating and ultimately interesting because they are complex. The researchers theorize that techniques of self can lead to personal growth and in turn contribute to cultural sustainability. Self-expression and belonging are two techniques of personal transformation supported by Cipher5, which work on a deeper level to strengthen identity (Wang, 2010, p. 68). Cipher5 is a space where personal identity can be cultivated through the elements of Hip Hop. This section looks at three components: 1) how identity is shaped in the cultural practices of Hip Hop through stage names and or personas, 2) how Hip Hop practices are in particular productive for Aboriginal youth in Edmonton, and 3) how Hip Hop reflects on how Cipher5 participation contributed to the researchers' development of self.

Identity development is a common practice in Hiphop Kulture. Most of the artists in the circle go by a stage name or persona. ${ }^{\text {iv }}$ In some cases, choosing a stage name may lead to the embodiment of a higher sense of self. For example, Shima, spoken word poet, freestyler and member of Cipher5 chose the name Dwennimmen, rooted in West African symbology, to strengthen her creative identity in a symbolic connection to her ethnic and cultural origins:

Despite being born in Edmonton, I am continually asked to recount a version of my history, my cultural and ethnic origin. My family comes from Jamaica and I have always felt an estrangement from my roots .... I wanted to find my link to the continent that gave rise to black civilizations that have impacted the world with education, art, architecture and more. I wanted that link to transcend the physical and subjective distance between myself and the power and influence of African knowledge through the entire black diaspora.

The Dwennimmen symbol represents the ram horns and the properties of strength, humility, learning and wisdom. I needed those four elements in my life at that time and still need them today. I began writing with the four virtues in mind, trying on the significance of this piece of ancient culture. I began living more honestly, feeling a deep sense of duty and connection to my own African-ness. I began freestyle rhyming and writing poetry with more clarity.

Living with Dwennimmen in mind keeps me focused, spiritually nourished, connected and vocal. I give thanks to the ancient name. (Shima, personal communication, June 19, 2014)

Shima made a conscious decision to develop a stronger identity; this technique of self is common in the Hiphop community and this process is often discussed at Cipher5. 
Identity development encourages hiphoppas to express themselves with confidence and clarity, and develops their creative abilities which contribute to the cultural sustainability of Edmonton Hiphop.

Through participation in Cipher5, Edmonton youth may discover a cultural practice in which to identify. As it is, "many adults may . . . assume that the young are damaged somehow and in need of fixing"; this notion is "further exacerbated for Indigenous youth" (Donald \& Krahn, 2014, p. 114). This is important to remember in Edmonton, where a significant and steadily growing Aboriginal population (Environics, 2010, p.17) poses an exceptional need for society to address "the ways in which Indian [Aboriginal] subjectivities have been legislated, marginalized, and pathologized" (Donald \& Krahn, 2014, p. 114). It is perhaps no surprise then that Aboriginal youth make up the majority of the Cipher 5 membership. Many members of the circle share stories of Hiphop as a saving force and as a way to re-connect with themselves. In a recent blog, Gyasi Ross explores his identification with hip-hop in the context of a childhood spent on the Blackfeet and Suquamish Reservation:

The songs contained survival messages, just like our own powerful songs-codes for future generations .... In a world where Natives are often taught that our traditions are evil or primitive or unworthy, we understood breakdancing's threat and energy and celebration of dance. It fit into our world well. We didn't have to choose "either/or," we could do both-celebrate our Native culture, as well as relate to this other culture thousands of miles away. (Ross, 2014, July 1, para. 20-21)

Ross's testimonial suggests how Aboriginal youth in Edmonton may identify with contemporary artistic practices without compromising the essence of their cultural backgrounds. With Brass's, Kirmayer's and Valaskasis' (2009) recognition that cultural identities are ever-changing, this blending of cultural practices is an example of "how the many strands of knowledge available today from diverse cultures of the world can be woven together in new patterns" (p. 440). In Edmonton, the researchers observed how various cultural identities weave together to sustain and develop Hiphop Kulture.

Subsequently, the researchers attested to the personal identity development provoked by Cipher5 participation. Through autoethnography, Roya Yazdanmehr elaborated on her experience:

I have developed a deeper understanding of myself: my social, political, musical, and religious positions, as well as a critical evaluation of these beliefs. I am dissecting my preconceived ideas of identity, challenging certain aspects that I do not like, 
evaluating who I have become, and deciding whether or not that is somebody I want to continue to be.

Following Foucault's advice that “one must take responsibility for inventing or producing one's own self” (Kendall \& Wickham, 1999, p. 30), in Cipher5 the researchers were challenged to question and re-build their own identities through the re-evaluation of their roots, values, and beliefs. From this experience they theorize identity development as a technique of self that will, when practiced at a personal level, contribute to the sustainability of Hiphop Kulture in Edmonton.

\section{Conclusions}

The researchers arrived at the understanding that cultural sustainability is influenced by Foucault's (1988) techniques of self (p.18). These techniques in the Edmonton Hip Hop community are identified as practices of belonging, self-expression, and identity development. Through the application of these techniques, Hip Hop practitioners have the ability to engage in a transformative process, becoming subjects of the very culture they are creating. The researchers documented how members of Cipher5 have used these techniques of self as a process of personal growth while simultaneously creating Hiphop Kulture. It is these processes that work together to contribute to the sustainability of Edmonton Hiphop Kulture.

* Authors: Diana Pearson and Roya Yazdanmehr are students in the Bachelor of Music program at MacEwan University.

Acknowledgement: We would like to express thanks to Dr. Michael B. MacDonald, professor at MacEwan University, Bachelor of Music program, for his mentoring, advice, and support regarding this research.

\section{References}

Alvarez III, T. T. (2012). Beats, rhymes, and life: Rap therapy in an urban setting. In S. Hadley and G. Yancy (Eds.), Therapeutic uses of rap and Hip Hop (pp. 117-128). New York: Routledge/Taylor and Francis Group.

Brass, G. M., Kirmayer, L. J., \& Valaskasis, G. G. (2009). Conclusion:

Healing/invention/tradition. In L. J. Kirmayer \& G. G. Valaskasis (Eds.), Healing traditions: The mental health of Aboriginal Peoples in Canada (pp. 440-472). Vancouver, B.C.: UBC Press. 
Donald D., \& Krahn, M. (2014). Abandoning pathologization: Conceptualizing indigenous youth identity as flowing from communitarian understandings. In S. Steinberg and A. Ibrahim (Eds.), Critical youth studies reader (pp. 114-129). New York: Peter Lang Publishing.

Environics Institute. (2010). Urban Aboriginal Peoples study: Edmonton report. Scarborough, ON: Interprovincial Group. Retrieved from http://uaps.ca/wpcontent/uploads/2010/02/UAPS-Edmonton-report.pdf

Foucault, M. (1988). Technologies of the self. In L. H. Martin, H. Gutman, \& P. Hutton (Eds.), Technologies of the self: A seminar with Michel Foucault (pp. 16-49). Boston: University of Massachusetts Press.

Foucault, M. (2004). The hermeneutics of the subject: Lectures at the College de France 1981-1982. New York: Picador.

Freire, P. (1974). Education for critical consciousness. New York: Continuum.

hooks, b. (1990). Yearning: Race, gender and cultural politics. Toronto, Ontario: Between the Lines.

hooks, b. (2009). Belonging: A culture of place. New York: Routledge/Taylor and Francis Group.

KazMega. (Writer, Producer \& Artist). (2014). Everybody's KINg [CD]. Edmonton, AB: Makebelieve Records.

Kendall, G., \& Wickham, G. (1999). Using Foucault's methods. Thousand Oaks: SAGE Publications.

KRS-ONE. (2000). KRS ONE: Brooklyn to the Bronx. Retrieved from http://www.krsone.com

KRS-ONE. (2009). The Gospel of Hip Hop: First instrument presented by KRS ONE for the Temple of Hip Hop. Brooklyn, NY: Powerhouse Books.

MacDonald, M. B. (2012). Hip-hop citizens: Local hip-hop and the production of democratic grassroots change in Alberta. In B. Porfilio and M. J. Biola (Eds.), HipHop(e): The cultural practice and critical pedagogy of international hip-hop (pp. 95-109). New York: Peter Lang Publishing. 
MacDonald, M. B. (2014). Cultural studies of youth culture aesthetics as critical aesthetic education. In S. Steinberg and A. Ibrahim (Eds.), Critical youth studies reader (pp. 434443). New York: Peter Lang Publishing.

Rabaka, R. (2013). The Hip Hop movement: From R \& B and the Civil Rights Movement to rap and the Hip Hop generation. Plymouth, UK: Lexington books.

Ross, G. (2014, July 1). Breakdances with wolves: When Hip Hop came to Indian reservations. Retrieved from http://gawker.com/breakdances-with-wolves-whenhip-hop-came-to-indian-re-1570730772 (Accessed July 1, 2014).

Wang, E. L. (2010). The Beat of Boyle Street: Empowering aboriginal youth through music making. New Directions in Youth Development, Spring(125), pp. 61-70. Accessed April 29, 2014. doi: 10.1002/yd.338.

i KRS-ONE's terminology from the Gospel of Hip Hop (2009) explains Hiphop Kulture as "the name of our unique community of consciousness" (p. 80).

iiThe name Cipher 5 comes from blending the word cypher, the term for a breakdancing circle, with the spelling of decipher, and 5 signifies knowledge, the fifth element of Hip Hop. (M.

MacDonald, personal communication, May 28, 2014)

iiiFoucault defines techniques, or technologies of self as processes "which permit individuals to effect by their own means or with the help of others a certain number of operations on their own bodies and souls, thoughts, conduct, and way of being, so as to transform themselves in order to attain a certain state of happiness, purity, wisdom, perfection, or immortality" (Foucault, 1988, p. 18).

ivexamples: Andre (Dre Pharoh or Point Blank), Kaz (KazMega), Donovan (Genesis), Shima (Dwennimmen). 